\title{
ESP Courses and Identity Formation: The Case of Introvert Students
}

\author{
Mojgan Rashtchi ${ }^{1} \&$ Reza Porkar ${ }^{1}$ \\ ${ }^{1}$ TEFL Department, Faculty of Foreign Languages, North Tehran Branch, Islamic Azad University, Iran \\ Correspondence: Mojgan Rashtchi, TEFL Department, Faculty of Foreign Languages, North Tehran Branch, \\ Islamic Azad University, Tehran, Iran. Tel: 98-2177-009-820. E-mail: mojgan.rashtchi@gmail.com
}

Received: March 10, 2020; Accepted: March 23, 2020; Published: March 24, 2020

\begin{abstract}
Identity formation is one of the main concerns of today's education and can have a vital role in ESP learners' future professional success. This study investigated whether the employment of interactive practices in ESP courses had any impact on the identity formation of introvert students. Initially, 200 undergraduate students majoring in Computer Sciences, Accounting, and Physical Education answered the introversion/extraversion section of the Myers-Briggs Type Indicator (MBTI) and Cheek and Briggs' Aspects of Identity Questionnaire (AIQ-IV). Based on their performance on MBTI, 90 learners with the extravert, introvert, and non-discriminating personality traits were selected from six classes and formed the three Extravert, Introvert, and Control $(\mathrm{n} 1=\mathrm{n} 2=\mathrm{n} 3=30)$ groups. The students had taken a Specialized English course in the second semester of their BA program. The classes lasted 14 sessions. During the treatment, the researchers employed different activities for teaching ESP. After the instruction, the participants took the AIQ-IV. The results of ANCOVA indicated that the Introvert group gained significantly higher scores on the identity questionnaire than the Extravert and Control groups. The results of paired samples t-tests showed that while introverts had improved considerably in all components of the identity questionnaire, the Extravert and Control groups did not show any changes. The findings indicated that in interactive classroom environments, introvert learners had more inclination than the extravert and mixed introvert and extravert learners toward a shift in identity. The study has implications for ESP teachers, practitioners, and educators.
\end{abstract}

Keywords: ESP learners, extraverts, identity, introverts, personality traits

\section{Introduction}

The appearance and growth of the concept of English for Specific Purposes (ESP) starting approximately in the 1960s correspond with the advent of globalization (Stojković, 2018). The ability to communicate in English has emerged as a persistent need for people across the globe since English is the language of science, technology, and commerce. However, general English courses inadequately respond to learners' specific needs and are not designed to enable learners to communicate in English in academic and occupational environments, efficiently (Belcher, Johns, \& Paltridge, 2011). While ESP and general English courses might have some semblance of curricular practices, they are distinct in teaching environment, methods, and content. While general English courses focus on proficiency in language skills and sub-skills, in ESP classes, the content of a particular major is connected to language to help learners gain mastery in a specific vocation (Campion, 2016). Therefore, the objective of ESP courses adapted to professional needs is to enable students to use language for job-related purposes. Thus, for ESP students, language is not merely a "cognitive phenomenon, the product of the individual's brain; it is also fundamentally a social phenomenon, acquired and used interactively, in a variety of contexts for myriad practical purposes" (Firth \& Wagner, 1997, p. 768). That is why ESP moves beyond linguistics and cognitive psychology (Block,2007) and considers different sociocultural factors, including identity as a decisive factor in language learning (Belcher \& Lukkarila, 2011). The responsibility of bridging nations and cultures through English has led educators to realize the importance of showing respect to diverse values, identities, and needs in the field of ELT (Albassri, 2016). Unlike general ELT practices, in ESP classes, the language, as the medium of instruction, is strictly functional, the exchange of messages is vital, and learning about the target culture and identity is central (Stojković, 2018). A focus on identity encourages reflection on how students see themselves, their education, and their profession, and how these views uniquely affect ESP students.

In Iran, where the present study was conducted, the language of instruction is students' L1 (Persian) except for English majors (e.g., TEFL, English Literature). For most university students, ESP courses do not seem to be of relevance. One reason is that the classes are mostly dull and far from the communicative purposes and vocational 
needs of learners. Although the content of the lessons is related to their field of study, the method of teaching in most classes resembles the Grammar-Translation. Students pass ESP courses without much interest in them. Lack of employing innovative teaching methods, deficiency in needs analysis, and the insufficiency of authentic ESP content lead to the failure of achieving fruitful objectives. Thus, the courses mostly fail to create an interactive environment in which students not only improve their language level but also develop a professional identity that could contribute to their future careers.

The purpose of the present study was to examine whether employing interactive classroom practices and implementing more modern teaching methods in ESP classes could specifically affect introvert students' identity. The reason for focusing on introvert learners was that they are usually known to be shy, unsociable, and reticent. This study aimed to examine whether communicative activities could bring a change in the personality characteristics of introvert ESP learners since the development of identity might help them gain confidence in their job prospects and develop a sense of belonging and persistence in their majors. Eysenck and Eysenck (1985) argue that while active social environments are appropriate driving forces for extraverts, quiet environments are where introverts seek their success. Since the components of identity are directly related to the social performance of individuals, and how they build relations in social interactions, the researchers of the current study were curious to explore whether introvert ESP learners would be successful in the identity formation process.

\section{Literature Review}

Identity and language learning have drawn increasing attention in SLA research since the publication of Peirce's (1995) seminal work examining the impact of identity relations on immigrant women's experiences of and investment in learning and using English. Identity formation is a social process that integrates the language learner with the language-learning context. Kroskrity $(2000$, p. 111) defines identity as the "linguistic construction of membership in one or more social groups or categories." Thus, language and communication work to produce varieties of identities in diverse contexts of interaction and intersect with one another. However, Hall (1996) considers the processes of identification, whereby individuals align themselves with groups, communities, or sets of interests, hobbies, values, beliefs, and practices. Various terms, such as social identity, organization identity, group identity, and professional identity, have been exploited in different studies. This study, however, adopts Norton's (2013) poststructuralist definition that asserts, "the way a person understands his or her relationship to the world, how that relationship is structured across time and space, and how the person understands possibilities for the future" (p. 4).

\subsection{The Role of Identity in Education}

In most countries, education is one of the factors that influence the quality of life standards. Identity is related to schooling as it affects the thoughts of people about who they are, what they think they can do and be, and where they belong. As a determining factor, identity is the motor of individuals for pursuing, persisting, and persevering in a field, and is essential in attracting and retaining underrepresented minorities.

Traditional pedagogy has focused on students' acquisition of knowledge without considering how their lives and experience mediate their beliefs. However, there is a growing recognition that identity formation must become an essential focus in education. Classrooms shape communities in which individuals engage in learning as a social activity and, thus, develop an identity. For Lave and Wenger (1991), learning is equal to the formation of identity; learners besides the acquisition of knowledge, become a member of a professional community.

The notion of learner identity introduced to linguistic research around the mid-20th century viewed learner identity singular and static (Duff, 2012), focusing on learning styles and motivations (Norton \&Toohey, 2011). With the advent of poststructural perspectives, the definition of identity was re-vitalized. Learning, as a complex process, entailed the acquisition of knowledge and practices of a particular disciplinary community and linked itself to how individuals understand themselves in the discipline in which they are engaged, broadly conceived of as identity development (Barton \& Tan, 2010). Classroom interactions and the roles learners take in groups form their identity. Hernández (2017) argues that language learners carry their identities molded through mental operations and interactions with others and the position they occupy within the EFL community.

Undoubtedly, learning a second language often results in negotiating, constructing, or reconstructing identity (Kinginger, 2004). Students socialize in their language classrooms and envision various images of themselves due to their engagement in social interaction (Hernández, 2017). Since language learning incorporates both a formal set of rules and the culture, a second language learner acquires a second identity, which involves not only the formation of self but also the perceptions of oneself within their community and the entire society (Aydemir, 2013). 
SLA has shifted from a broad focus on linguistic pedagogy to a sharper emphasis on learner identity that facilitates the process of language learning (Albassri, 2016). Lujić (2018) maintains that language learners' identity is not something they are, preferably something they do, or, more precisely, a sequence of acts. Thus, when a learner participates in conversations in which their content is related to what $\mathrm{s} /$ he has learned in the language classroom, it can be assumed that s/he has developed an appropriate professional identity.

One advantage of studying ESP learners' identity is articulated by Allport (1954) in the contact hypothesis. Allport suggests that the interaction of one cultural group with other similar groups can result in the reduction of prejudice. According to the tenets of this theory, cultural bias and adverse stereotyping will diminish if four requirements are present, viz. equal status, common goals, intergroup cooperation, and institutional support. Closely related to this view is the necessity to incorporate learner identity construction in ESP needs analysis (Belcher \& Lukkarila, 2011; Brown, 2016).

The development of identity helps learners become aware of the roles they have in social contexts (Al Rhyiami, 2014). The responsibility of teachers and practitioners in selecting appropriate materials and teaching methods is crucial in ESP courses since they both help to recognize learners' needs (Rajagopalan, 2005) and respect their identity (Rottava \& Silva, 2014).

\subsection{Personality Factors}

In the process of foreign language learning, many factors interact to influence learners' achievements. Studying factors such as motivation, emotion, attitude, and personality traits contribute to learning about the process of second or foreign language learning. Among these factors, personality or characteristics that determine potentialities and collective abilities exclusive to an individual is of vital role (Tejada Reyes, 2018). Individual differences encompass a vast variety of personality factors, such as self-esteem, self-efficacy, motivation, inhibition, empathy, language ego and aptitude, and cognitive and affective factors, such as intelligence and risktaking (Pavičić Takač \& Požega, 2011).

Nowadays, many researchers explore different personality types from different perspectives. This query has led to the appearance of the personality theory, which assumes that a unique and unchanging pattern of traits and temperaments characterizes an individual (Sharp, 2008). For Eysenck (1972), personality factors embrace three factors of extraversion, neuroticism, and psychoticism. However, later, Costa Jr and McCrae (1985) introduced the Big Five markers and developed the NEO Five-Factor Inventory, which assesses how respondents typically think, act, and feel. The inventory measures the five domains of extraversion, agreeableness, conscientiousness, neuroticism, and openness to experience.

Myers-Briggs type indicator (MBTI) is another instrument that utilizes Jung's personality traits for discovering individuals' characteristics. The inventory (Myers, McCaulley, Quenk, \& Hammer, 2009) focuses on measuring individuals on four dimensions comprising of opposite pairs: Extraversion/Introversion (E-I), Sensation/Intuition (S-N), Thinking/Feeling (T-F), and Judgment/Perception (J-P), resulting in 16 possible psychological types.

Learners' personality characteristics may eventually lead to more or less successful learning of the second language (Ellis, 1997). Arnold and Murphey (2013), in their quest for exploring Stevick's role in language teaching, clearly point out to his affirmation that success in language learning depends to a large extent on what goes on inside and between the people in the classroom. This view implies that considering the inside or the intrapersonal aspects of learners, can help teachers make learning more meaningful. In contrast, the second aspect, the 'between' reminds us that often meaning is not made alone. Thus, success depends less on things and more on people. With 'inside,' Stevick refers to individual factors such as motivation, self-esteem, anxiety, inhibition, tolerance of ambiguity, learning styles, introversion/extraversion, and self-efficacy. Successful learning is partially due to the relation between individuals and their interactions in the classroom situation (Arnold, 2019). Most of the theories about personality factors not only include the introversion and extraversion dimension but also have very similar notions of the construct. Extraversion and introversion form two ends of a continuum. While extraverts are perceived to be outgoing, expressive, aggressive, and risk-taking, introverts seem to be shy, self-centered, and less sociable (Rashtchi \& Keyvanfar,2007). The dichotomy deals with where individuals' source of energy and motivation lies; in other people or themselves. In other words, the trait examines whether a person prefers to do team-work or favors individual activities (Sharp, 2004). Extraverts have high inhibition, meaning that in case of trauma, their brain would become numb and will remember very little, whereas introverts' brains will remember everything that happened (Boeree, 1998). Kayaoğlu (2013) showed that intro- and extraverted learners behave differently in language learning contexts since they implement different strategies in their learning process.

Linguists, in general, have regarded extraversion as the preferred and helpful trait for language learning (Zafar, Zaved Khan, \& Meenakshi, 2017). This view finds support from Cook (1994), who refers to many language 
acquisition theories that claim extraverts are better language learners since they tend to be sociable, more likely to join groups, and more inclined to have social contacts. Many language teachers will vouch for the fact that it is more pleasurable to work with extraverted students. This belief has led to the assumption that an introverted student is a slow learner of a second language (L2). This notion was the researchers' driving force to examine whether creating an active classroom environment could help introverts develop a positive professional persona.

Several studies have focused on the relationship of identity with various factors. For instance, Collinger (1995) investigated three identity styles based on Berzonsky's Model within the five-factor model of personality. The results obtained from 189 undergraduate students indicated that the information-oriented and normative identity scales had a positive correlation with extraversion, agreeableness, and conscientiousness. Furthermore, there was a positive relationship between the identity style of information-oriented and openness, while it had a negative correlation with the normative identity style. Mujembari, Sharifi, and Looyeh (2011) investigated the relationship between identity and the five personality factors of 550 high school students, who belonged to various religious groups, namely, Muslim, Zoroastrian, and Christian. The data obtained from an identity questionnaire and NEO's five-factor personality test showed that the factors had a significant role in the formation of the identity of the teenagers. In a survey called Endangered Language Learning Emotion Scale (ELLES), Achilles (2018) studied the connection of identity, emotions, and language with endangered language learning. The findings revealed that both isolation and lack of resources endangered a language, and the existence of community, dedication, and positivity could halt the process of endangerment. Another finding was the presence of a strong relationship between emotion and identity and the development of positive communities.

Undoubtedly, personality traits are decisive contributors to identity formation and may serve as expressions of identity as well as determinants of other factors that contribute to identity achievement. In their study on 2,092 students, Lounsbury, Levy, Leong, and Gibson (2007) found that personality traits (Agreeableness, Conscientiousness, Emotional Stability, Extraversion, and Openness) could be influential factors in the sense of identity. Clancy and Dollinger (1993) also found a positive relationship between extraversion and identity achievement and a negative correlation between neuroticism and identity achievement. They concluded that there are "clear connections between identity and personality dimensions" (p. 241).

Poststructural theories, which depict the individual as diverse, contradictory, dynamic, and changeable over time and social space, have influenced the philosophy of identity. This view is in contrast with the definitions which presuppose individuals to possess essential, unique, and coherent core identity, that is to say, extravert versus introvert or motivated versus unmotivated (Norton \& Toohey, 2002). Thus, the role of the classroom as the source of the emergence of a wide range of interaction patterns that are influential in the formation of learners' identity seems to overshadow the role of personality traits in language learning. The ability of the classroom practices to encourage participation and involvement can affect learners' characteristics such as self-confidence, motivation, and sociability, leading to the development of a sense of identity.

\subsection{Research Questions}

To examine whether interactive classroom practices in ESP courses could affect the identity of introvert learners in comparison to extravert learners and students with mixed introvert and extravert traits (control), the researchers formulated the following research questions.

RQ1: Do the three groups of introverts, extraverts, and control differ in the components of identity before participating in ESP courses?

RQ2: Do Introvert, Extravert, and Control groups perform differently on the identity questionnaire after taking part in ESP courses?

RQ3: Does the identity of the Extravert group change after participation in ESP courses?

RQ4: Does the identity of the Introvert group change after participation in ESP courses?

RQ5: Does the identity of the Control group change after participation in ESP courses?

\section{Method}

\subsection{Participants}

Two hundred ESP students (127 females and 73 males) from three majors of Accounting, Computer Sciences, and Physical Education took the introversion/extraversion section of the Myers-Briggs Type Indicator (MBTI) questionnaire (Myers, McCaulley, Quenk, \& Hammer, 2009) and Cheek and Briggs' (2013) Aspects of Identity Questionnaire (AIQ-IV). The students, selected based on convenience sampling, were taking a Specialized English course in the second semester of their BA program at Islamic Azad University, North Tehran Branch. The initial 
results of the MBTI showed that 22 of the students answered all options specific to extraverts, whereas only 13 responded to all items indicative of introversion. However, 100 students had selected the options almost equal; therefore, they stood in the middle of extraversion/introversion dichotomy. Thirty were more inclined toward extraversion, and 35 to introversion. Thus, the researchers decided to consider the participants in three groups of 30 introverts (Introvert group), 30 extraverts (Extravert group), and 30 mixed introvert and extravert students (Control group). It is worth mentioning that it was not feasible to separate the students and form three groups. Therefore, the researchers decided to follow them in their groups and administer the post-test at the final exam session performed by the staff of the faculty. Table 1 shows the demographic information of the participants. The results of the chi-square showed no statistically significant differences among the groups regarding gender.

Table 1. Demographic Information of the Participants

\begin{tabular}{ccccccc}
\hline \multirow{2}{*}{ Gender } & \multicolumn{2}{c}{ Extravert Group } & \multicolumn{2}{c}{ Introvert Group } & \multicolumn{2}{c}{ Control Group } \\
& Frequency & Percent & Frequency & Percent & Frequency & Percent \\
\hline Male & 11 & 36.6 & 10 & 33.3 & 12 & 40 \\
Female & 19 & 63.4 & 20 & 66.7 & 18 & 60 \\
Total & 30 & 100 & 30 & 100 & 30 & 100 \\
\hline
\end{tabular}

Chi-Square Test $\quad \chi^{2}=0.29 \mathrm{df}=2 \mathrm{p}=0.08$

As shown in Table 2, the age of most students was between 20 and 25 across the three groups. The age average of

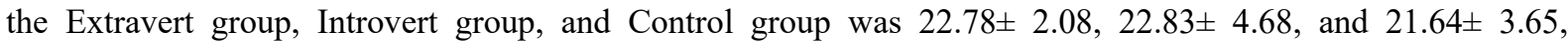
respectively. The one-way ANOVA showed no statistically significant differences among the age of the groups $(\mathrm{p}=0.055)$.

Table 2. Frequency of the Participants' Age in the Groups

\begin{tabular}{ccccccc} 
Groups & \multicolumn{2}{c}{ Extravert Group } & \multicolumn{2}{c}{ Introvert Group } & \multicolumn{2}{c}{ Control Group } \\
Majors & Frequency & Percent & Frequency & Percent & Frequency & Percent \\
\hline Accounting & 13 & 43.3 & 14 & 46.6 & 13 & 43.3 \\
Physical Education & 6 & 20 & 3 & 10.1 & 5 & 16.7 \\
Computer Science & 11 & 36.7 & 13 & 43.3 & 12 & 40 \\
Total & 30 & 100 & 30 & 100 & 30 & 100 \\
\hline Chi-Square test & & $\chi^{2}=2.24 \mathrm{df}=4 \mathrm{p}=0.69$ & \\
\hline
\end{tabular}

Table 3 shows that most of the participants in the groups belonged to Accounting. However, the results of the chisquare test showed no statistically significant difference regarding the field of study $(\mathrm{p}=0.69)$.

Table 3. Distribution of the Groups Across Fields of Study

\begin{tabular}{lllllll}
\hline Groups & \multicolumn{2}{l}{ Extravert Group } & \multicolumn{2}{l}{ Introvert Group } & \multicolumn{2}{l}{ Control Group } \\
Age & Frequency & Percent & Frequency & Percent & Frequency & Percent \\
\hline$<\mathbf{2 0}$ & 8 & 26.6 & 6 & 20 & 7 & 23.3 \\
$\mathbf{2 0 - 2 5}$ & 20 & 66.6 & 23 & 76.6 & 21 & 70 \\
$>\mathbf{2 5}$ & 2 & 6.8 & 1 & 3.4 & 2 & 6.7 \\
Total & 30 & 100 & 30 & 100 & 30 & 100 \\
\hline SD \pm Mean & $22.78 \pm 2.08$ & & $22.83 \pm 4.68$ & & $21.64 \pm 3.65$ & \\
Min- Max & $18-26$ & & $18-26$ & & $18-27$ & \\
ANOVA Test & $\mathrm{F}=3.16 \mathrm{p}=0.055$ & & & & \\
\hline
\end{tabular}

\subsection{Instruments}

The researchers employed three tools for data collection. The first one was the introversion/extraversion section of the MBTI questionnaire (Myers et al., 2009). This section has 25 questions, and the respondents have two options to select. Myers et al. (2009) reported that the reliability index of the introversion/extraversion section obtained from a sample of 3036 individuals was 0.90. Also, in their pilot study, Rashtchi and Sanayi Mashhoor (2019) found the reliability indices of 0.81 for the introversion and 0.86 for the extraversion sections of the questionnaire. 
Another instrument was Cheek and Briggs' (2013) Aspects of Identity Questionnaire (AIQ-IV), which all students took at the onset of the study. However, only the target students answered it after participation in ESP courses. The questionnaire has 45 items on a five-point Likert scale ( $1=$ Not important to my sense of who I am, $2=$ Slightly important to my sense of who I am, 3 = Somewhat important to my sense of who I am, $4=$ Very important to my sense of who I am, and 5= Extremely important to my sense of who I am). The five different components of identity that the instrument embraces are Personal Identity Orientation (PIO), Relational Identity Orientation (RIO), Social Identity Orientation (SIO), Collective Identity Orientation (CIO), and Special Items (SI). The researchers computed the reliability index of the questionnaire after the first administration (to 200 learners) via Cronbach's alpha. The reliability index appeared to be quite acceptable ( $\mathrm{r}=0.85)$. AIQ-IV is accessible at http://www.midss.ie

Also, the researchers used a needs analysis survey at the onset of the study to discover the expectations of the students from the ESP courses and the type of activities they preferred to have (Appendix A).

\subsection{Materials}

Based on the results of the needs analysis survey, the researchers prepared a seven-week syllabus (each week, two sessions). They selected seven passages related to the learners' field of study and wrote some comprehension questions for the articles. They specified the necessary grammatical points which needed explicit instruction and prepared some grammar tests to enhance learning. Also, they made some true-false and fill-in-the-blank sentences for more practice. The researchers also arranged PowerPoint slides containing the highlights of each lesson and found some related pictures or short films to stimulate learning. Additionally, they downloaded some field-related videos from YouTube for extra-curricular activities.

\subsection{Procedure}

First, 200 ESP learners in six different classes took the extraversion/introversion section of the MBTI and AIQIV. Based on the results in each class, the target participants were identified. The classes lasted seven weeks, each week, two sessions, each session 90 minutes. For each class, the teacher, who was one of the researchers, created a WhatsApp group to enhance the students' contact with ESP during the week.

Each session, the teacher first showed some pictures or slides related to the topic of the week. Then he divided the class into groups of three and asked the groups to go through the reading passage and underline as many unknown words as they could in five minutes. During this activity, the participants were quite active and tried to divide the work among themselves. In the next step, the teacher asked the students to use their mobile phones and look for the meaning of the words. They usually looked for the words in google or used the dictionaries they had installed on their cell phones. Students cooperated in groups to find the meaning of the vocabulary and negotiated their L1 equivalents. In the next step, the teacher presented the PowerPoint slides he had prepared based on the highlights of the passage. In the last step, the students got engaged in shared reading and answered the subsequent comprehension questions in groups. The teacher taught the grammatical points which he had pinpointed before and responded to students' questions. As the final step, the students took the grammar tests.

During the week, the teacher uploaded some videos related to learners' field of study from YouTube. The students were required to watch the movies and formulate questions that could boost classroom discussion in the following session. The teacher gave extra points to students whose questions were more challenging. The students were free to share professional ideas and impressions in the WhatsApp group or ask questions related to the lesson. The virtual group enhanced communication among learners and encouraged them to share ideas with classmates.

In the next session, first, the teacher wrote on the board five or six questions he had extracted from the students' questions on the WhatsApp group. Then students in groups discussed the answers. They could refer to the passage, look for the meaning of the words, and negotiate with other groups. One of the students in each group read the answers to the class. Also, one or two of the students had to lecture on a related topic. Lecturers were supposed to prepare PowerPoint slides and pictures regarding the subject of their talk. The lecturers who could encourage their classmates' participation were given extra credits.

The students took the final exam on the $15^{\text {th }}$ session; only the target participants $(\mathrm{n}=90)$ answered the AIQ-IV questionnaire.

\section{Results}

First, the researchers performed the Kolmogorov-Smirnov (K-S) test to ensure that the distribution of the scores was normal. As Table 4 shows, the $p$-value for all sub-sections of the questionnaire both in the pretest and posttest is not statistically significant ( $>0.05$ ). Thus, employing parametric tests due to the normality of the distributions was legitimate. 
Table 4. K-S Test for Normality of the Scores for Different Sections of AIQ-IV

\begin{tabular}{|c|c|c|c|c|}
\hline \multirow[t]{2}{*}{ Components } & \multicolumn{2}{|c|}{ Pre-test } & \multicolumn{2}{|c|}{ Post-test } \\
\hline & K-S & Sig. & K-S & Sig. \\
\hline PIO & 0.142 & 0.072 & 0.143 & 0.06 \\
\hline RIO & 0.112 & 0.270 & 0.135 & 0.124 \\
\hline SIO & 0.145 & 0.059 & 0.132 & 0.130 \\
\hline CIO & 0.141 & 0.074 & 0.123 & 0.2 \\
\hline SI & 0.110 & 0.273 & 0.130 & 0.122 \\
\hline
\end{tabular}

\subsection{Research Question One}

Table 5 shows the descriptive statistics and the results of the one-way ANOVA run before the treatment. As shown, the Extravert group scored higher than the Introvert and Control groups in all components of the AIQ-IV. The results showed that there was a statistically significant difference between the groups in all sub-sections of AIQIV $(\mathrm{p}<0.05)$.

Table 5. Results of AIQ-IV Before the Treatment

\begin{tabular}{|c|c|c|c|c|c|c|c|}
\hline \multirow[t]{2}{*}{ Components } & \multicolumn{2}{|c|}{ Extravert group } & \multicolumn{2}{|c|}{$\begin{array}{l}\text { Introvert } \\
\text { group }\end{array}$} & \multicolumn{2}{|l|}{$\begin{array}{c}\text { Control } \\
\text { group }\end{array}$} & \multirow{2}{*}{ ANOVA test } \\
\hline & Mean & SD & Mean & SD & Mean & SD & \\
\hline PIO & 47.33 & 1.44 & 22.73 & 3.25 & 36.43 & 11.63 & $F=99.75 \mathrm{p}<0.001$ \\
\hline RIO & 48.33 & 1.39 & 22.80 & 4.13 & 36.60 & 11.77 & $\begin{array}{l}F=93.23 \\
\mathrm{p}<0.001\end{array}$ \\
\hline SIO & 31.73 & 2.19 & 17.57 & 4.33 & 24.60 & 7.81 & $\begin{array}{l}F=53.31 \\
\mathfrak{p}=0.02\end{array}$ \\
\hline CIO & 35.83 & 2.80 & 20.17 & 4.01 & 27.97 & 10.57 & $F=40.65 \mathrm{p}<0.001$ \\
\hline SI & 20.37 & 1.81 & 10.70 & 3.01 & 16.30 & 4.73 & $F=60.90 \mathrm{p}<0.001$ \\
\hline
\end{tabular}

Table 6 shows the result of the Bonferroni test run to compare the groups before the treatment. As the results indicate, there is a statistically significant difference between the groups in all sub-sections of AIQ-IV in favor of the Extravert group $(\mathrm{p}<0.001)$. In other words, the Extravert group performed significantly better in the AIQ-IV than the Introvert and Control groups. Thus, the answer to the first research question was negative.

Table 6. Bonferroni Test Between Groups Before the Treatment

\begin{tabular}{llllllll}
\hline AIQ-IV & $\begin{array}{l}\text { Control } \\
\text { Group }\end{array}$ & Test Groups & $\begin{array}{l}\text { Mean } \\
\text { Difference }\end{array}$ & Std. Error & Sig. & $\begin{array}{l}\mathbf{9 5 \%} \\
\text { interval } \\
\text { Lower } \\
\text { Bound }\end{array}$ & $\begin{array}{l}\text { Confidence } \\
\text { Upper } \\
\text { Bound }\end{array}$ \\
\hline \multirow{2}{*}{ PIO } & Control & Extravert & -11.900 & 1.814 & .000 & -16.33 & -7.47 \\
& & Introvert & 13.700 & 1.814 & .000 & 9.27 & 18.13 \\
RIO & Control & Extravert & -11.733 & 1.872 & .000 & -16.30 & -7.16 \\
& & Introvert & 13.800 & 1.872 & .000 & 9.23 & 18.37 \\
SIO & Control & Extravert & -7.133 & 1.372 & .000 & -10.48 & -3.78 \\
& & Introvert & 7.033 & 1.372 & .000 & 3.68 & 10.38 \\
CIO & Control & Extravert & -7.867 & 1.737 & .000 & -12.11 & -3.63 \\
& & Introvert & 7.800 & 1.737 & .000 & 3.56 & 12.04 \\
SI & \multirow{2}{*}{ Control } & Extravert & -4.067 & .880 & .000 & -6.21 & -1.92 \\
\hline
\end{tabular}

\subsection{Research Question 2}

The researchers conducted an ANCOVA to answer the second research question. As shown in Table 7, after the treatment, the highest mean for the Introvert group $(\mathrm{M}=49.27, \mathrm{SD}=1.57)$ and the Extravert group $(\mathrm{M}=48.43$, $\mathrm{SD}=1.50)$ was on PIO. However, the Control group's highest mean $(\mathrm{M}=36.63, \mathrm{SD}=11.80)$ was on RIO. 
Table 7. ANCOVA Results of AIQ-IV After the Treatment

\begin{tabular}{|c|c|c|c|c|c|c|c|}
\hline \multirow{2}{*}{$\begin{array}{l}\text { Components } \\
\text { of AIQ-IV }\end{array}$} & \multicolumn{2}{|c|}{ Extravert Group } & \multicolumn{2}{|c|}{ Introvert Group } & \multicolumn{2}{|c|}{ Control Group } & \multirow{2}{*}{ ANCOVA Test } \\
\hline & Mean & SD & Mean & SD & Mean & SD & \\
\hline PIO & 48.43 & 1.50 & 49.27 & 1.57 & 36.47 & 11.58 & $\begin{array}{l}F=472.43 \\
\mathrm{p}<0.001\end{array}$ \\
\hline RIO & 47.45 & 1.43 & 46.34 & 1.50 & 36.63 & 11.80 & $\begin{array}{l}F=396.53 \\
\mathrm{p}<0.001\end{array}$ \\
\hline SIO & 38.71 & 2.097 & 31.63 & 1.95 & 24.63 & 7.81 & $\begin{array}{l}F=146.30 \\
p<0.02\end{array}$ \\
\hline CIO & 36 & 2.80 & 35.77 & 2.62 & 28 & 10.52 & $F=161.36 \mathrm{p}<0.001$ \\
\hline SI & 20.43 & 1.79 & 20.47 & 1.73 & 16.37 & 4.76 & $\begin{array}{c}F=96.11 \\
\mathrm{p}<0.001\end{array}$ \\
\hline
\end{tabular}

Post hoc comparisons using the Bonferroni test indicated that Extravert and Introvert groups outperformed the Control group in all components of the questionnaire (Table 8). The statistically significant differences between the Introvert, Extravert, and Control groups led to an affirmative answer to the second research question.

Table 8. Results of Post Hoc Bonferroni Test After the Treatment

\begin{tabular}{|c|c|c|c|c|c|c|c|c|}
\hline $\begin{array}{l}\text { Components } \\
\text { AIQ-IV }\end{array}$ & of & $\begin{array}{l}\text { Control } \\
\text { Group }\end{array}$ & $\begin{array}{l}\text { Test } \\
\text { Groups }\end{array}$ & $\begin{array}{l}\text { Mean } \\
\text { Difference }\end{array}$ & $\begin{array}{l}\text { Std. } \\
\text { Error }\end{array}$ & Sig. & $\begin{array}{l}95 \% \\
\text { Interval } \\
\text { Lower } \\
\text { Bound } \\
\end{array}$ & $\begin{array}{l}\text { Confidence } \\
\text { Upper } \\
\text { Bound }\end{array}$ \\
\hline \multirow{2}{*}{ PIO } & & \multirow{2}{*}{ Control } & Extravert & -20.31 & 0.751 & .000 & -25.81 & -15.36 \\
\hline & & & Introvert & -24.242 & 0.792 & .000 & -26.177 & -22.308 \\
\hline \multirow{2}{*}{ RIO } & & \multirow{2}{*}{ Control } & Extravert & -22.464 & 1.181 & .000 & -25.35 & -19.57 \\
\hline & & & Introvert & -23.865 & 0.850 & .000 & -25.941 & -21.788 \\
\hline \multirow{2}{*}{ SIO } & & \multirow{2}{*}{ Control } & Extravert & -10.755 & 0.953 & .000 & -13.110 & -8.448 \\
\hline & & & Introvert & -12.465 & 0.729 & .000 & -14.245 & -10.686 \\
\hline \multirow{2}{*}{ CIO } & & \multirow{2}{*}{ Control } & Extravert & -13.309 & 1.02 & .000 & -15.804 & -10.815 \\
\hline & & & Introvert & -14.509 & 0.815 & .000 & -16.499 & -12.519 \\
\hline \multirow{2}{*}{ SI } & & \multirow{2}{*}{ Control } & Extravert & -7.063 & 0.753 & .000 & -8.900 & -5.225 \\
\hline & & & Introvert & -8.172 & 0.590 & .000 & -9.612 & -6.722 \\
\hline
\end{tabular}

In sum, the results of the ANCOVA showed that after the treatment, there was a statistically significant difference between the PIO of the groups $(\mathrm{p}<0.001)$. The Bonferroni post hoc test revealed that the Introvert $(\mathrm{M}=49.27$, $\mathrm{SD}=1.57)$ and Extravert groups $(\mathrm{M}=48.43, \mathrm{SD}=1.50)$ did significantly better than the Control group $(\mathrm{M}=36.47$, $\mathrm{SD}=11.58)$ on $\mathrm{PIO}$ component. Also, there was a statistically significant difference between the groups regarding RIO $(\mathrm{p}<0.001)$. The Bonferroni test showed that the Introvert group $(\mathrm{M}=46.34, \mathrm{SD}=1.50)$ and Extravert group $(\mathrm{M}=47.45, \mathrm{SD}=1.43)$ had significantly higher performance on $\mathrm{RIO}$ than the Control group $(\mathrm{M}=36.63, \mathrm{SD}=11.80)$, $\mathrm{p}<0.001)$.

Regarding SIO, the Introvert group $(\mathrm{M}=31.63, \mathrm{SD}=1.95), \mathrm{p}=0.012$ and Extravert group $(\mathrm{M}=38.71, \mathrm{SD}=2.09)$, $\mathrm{p}<0.001$ outperformed the Control group $(\mathrm{M}=24.63, \mathrm{SD}=7.81)$. Additionally, the means obtained from the CIO component of the questionnaire for the Introvert group $(\mathrm{M}=35.77, \mathrm{SD}=2.62)$ and the Extravert group $(\mathrm{M}=36$, $\mathrm{SD}=2.80)$ was significantly different from the Control group $(\mathrm{M}=28, \mathrm{SD}=10.52), \mathrm{p}<0.001$. As Table 8 illustrates, the mean of the Introvert group $(M=20.43, S D=1.79)$ and the Extravert group $(M=20.47, S D=1.73)$ was statistically different from the Control group $(\mathrm{M}=16.37, \mathrm{SD}=4.76), \mathrm{p}<0.001$. The researchers infer that introvert and extravert students could benefit more from ESP courses than students with mixed introvert and extravert traits.

\subsection{Research Questions 3, 4, and 5}

The researchers performed three paired samples t-tests to answer research questions three, four, and five. The aim was to examine whether participation in ESP courses could cause any changes in the identity of the students. Table 9 shows the results of the paired sample t-test of the Extravert group. The result of the $\mathrm{t}(29)=1.8, \mathrm{p}=0.08$ for PIO, $\mathrm{t}(29)=1.82, \mathrm{p}=0.07$ for RIO, $\mathrm{t}(29)=1.68, \mathrm{p}=0.1$ for SIO, $\mathrm{t}(29)=1.72, \mathrm{p}=0.09$ for $\mathrm{CIO}$, and $\mathrm{t}(29)=1.43, \mathrm{p}=0.16$ for 
SI showed that there was no statistically significant difference between the components of AIQ-IV of the extraverts before and after the treatment. That is to say, participation in ESP courses could not change their identity.

Table 9. Paired Samples t-Test on AIQ-IV for Extravert Group Before and After Treatment

\begin{tabular}{cccccc}
\hline $\begin{array}{c}\text { Components of } \\
\text { AIQ-IV }\end{array}$ & \multicolumn{2}{c}{ Before Treatment } & \multicolumn{2}{c}{ After Treatment } & \multirow{2}{*}{ Paired-samples t-Test } \\
\hline PIO & 47.33 & 1.44 & 48.43 & 1.50 & $t=-1.795 \mathrm{df}=29 \mathrm{p}=0.083$ \\
RIO & 48.33 & 1.39 & 47.45 & 1.43 & $t=-1.824 \mathrm{df}=29 \mathrm{p}=0.074$ \\
SIO & 31.73 & 2.19 & 31.87 & 2.097 & $t=-1.682 \mathrm{df}=29 \mathrm{p}=0.103$ \\
CIO & 35.83 & 2.80 & 36 & 2.80 & $t=-1.720 \mathrm{df}=29 \mathrm{p}=0.096$ \\
SI & 20.37 & 1.81 & 20.43 & 1.79 & $t=-1.43 \mathrm{df}=29 \mathrm{p}=0.161$ \\
\hline
\end{tabular}

Table 10 shows the results of the paired sample t-test of the Introvert group. The result of the $t(29)=33, p<0.001$ for PIO, $\mathrm{t}(29)=30, \mathrm{p}<0.001$ for RIO, $\mathrm{t}(29)=16.37, \mathrm{p}<0.001$ for $\mathrm{SIO}, \mathrm{t}(29)=16.7, \mathrm{p}<0.001$ for $\mathrm{CIO}$, and $\mathrm{t}(29)=33$, $\mathrm{p}<0.001$ for SI showed that there was a statistically significant difference between the components of AIQ-IV of the introverts before and after the treatment. That is to say, participation in ESP courses could change the identity of the introverts.

Table 10. Paired Samples t-Test on AIQ-IV for Introvert Group Before and After Treatment

\begin{tabular}{llllll} 
Components of & \multicolumn{2}{c}{ Before Treatment } & \multicolumn{2}{l}{ After Treatment } & \multirow{2}{*}{ Paired-samples t-Test } \\
AIQ-IV & Mean & SD & Mean & SD & \\
\hline PIO & 22.73 & 3.25 & 48.27 & 1.57 & $t=-32.980 \mathrm{df}=29 \mathrm{p}<0.001$ \\
RIO & 22.80 & 4.13 & 46.34 & 1.50 & $t=-29.940 \mathrm{df}=29 \mathrm{p}<0.001$ \\
SIO & 17.57 & 4.33 & 31.63 & 1.95 & $t=-16.370 \mathrm{df}=29 \mathrm{p}<0.001$ \\
CIO & 20.17 & 4.01 & 35.77 & 2.62 & $t=-16.700 \mathrm{df}=29 \mathrm{p}<0.001$ \\
SI & 10.70 & 3.01 & 20.47 & 1.73 & $t=-32.980 \mathrm{df}=29 \mathrm{p}<0.001$ \\
\hline
\end{tabular}

Table 11 shows the results of the paired samples t-test for the Control group. The result of the $t(29)=1.35, p=0.17$ for PIO, $\mathrm{t}(29)=1, \mathrm{p}=0.32$ for $\mathrm{RIO}, \mathrm{t}(29)=1.85, \mathrm{p}=0.075$ for $\mathrm{SIO}, \mathrm{t}(29)=1.8, \mathrm{p}=0.07$ for $\mathrm{CIO}$, and $\mathrm{t}(29)=1.5, \mathrm{p}=0.18$ for SI showed that there was no statistically significant difference between the components of AIQ-IV before and after the treatment in the group. That is to say, participation in ESP courses could not change the identity of this group.

Table 11. Paired Samples t-Test on AIQ-IV for Control Group Before and After Treatment

\begin{tabular}{llllll}
\hline \multirow{2}{*}{ Components of AIQ-IV } & \multicolumn{2}{c}{ Before Treatment } & \multicolumn{2}{l}{ Before Treatment } & \multirow{2}{*}{ Paired-samples t-Test } \\
& Mean & SD & Mean & SD & \\
\hline PIO & 36.43 & 11.63 & 36.47 & 11.58 & $t=-1.35 \mathrm{df}=29 \mathrm{p}=0.171$ \\
RIO & 36.60 & 11.77 & 36.63 & 11.80 & $t=-1 \mathrm{df}=29 \mathrm{p}=0.326$ \\
SIO & 24.60 & 7.81 & 24.63 & 7.81 & $t=-1.85 \mathrm{df}=29 \mathrm{p}=0.07$ \\
CIO & 27.97 & 10.57 & 28 & 10.52 & $t=-1.80 \mathrm{df}=29 \mathrm{p}=0.075$ \\
SI & 16.30 & 4.73 & 16.37 & 4.76 & $t=-1.493 \mathrm{df}=29$ \\
& & & & &
\end{tabular}

\section{Discussion}

The results of the one-way ANOVA at the onset of the study showed that the Extravert group gained higher scores on all components of the AIQ-IV before participating in ESP courses. However, after the treatment, the Introvert group performed significantly better than the Extravert and Control groups on the identity questionnaire. This finding shows that introverts benefitted more from the classroom activities, were more liable toward behavior change, and could successfully establish social relations in the classroom community. Therefore, the researchers assume that in goal-oriented situations, as in ESP classes, introverts are more successful in identity formation. It is worth mentioning that the classroom practices were mostly interactive and cooperative; thus, although they were 
attractive for the extravert learners, they conformed with the characteristics usually attributed to extraverts. This finding is inconsistent with Eysenck and Eysenck's (1985) view, who argue that introverts find success in quiet environments.

Moreover, the researchers employed technology to encourage learners to participate more actively in classroom procedures. One interpretation based on previous research studies (e.g., Rashtchi \& Aghili, 2014; Rashtchi \& Khoshnevisan, 2009; Rashtchi \& Tollabi Mazraehno, 2019) is that the use of technology and social media can stimulate social interaction among introvert ESP learners. Employing technology could help the participants realize that they are members of a broader community (Weyreter \& Viebrock, 2014). Also, student lectures helped them use their language skills in a professional context and led to the awareness of the role of language knowledge in facilitating work-related communications. A central feature in the process of professional identity formation is learning to talk (and write) as members of the profession do. The researchers of the current study, in line with Bucholtz and Hall (2005), postulate that identity is the product of linguistic practices in ESP. However, the role of extravert students in classroom activities needs attention. They stimulated classroom interactions and initiated conversations. Therefore, successful language learning in ESP classes requires teachers to use stimulating techniques and strategies to involve learners in the process of learning. Also, they should view the characteristics of the extravert learners as the hidden force that, if used purposefully, can motivate the class.

A note is also worth to mention regarding the Control group. The results of MBTI showed that they could neither be considered as introverts nor as extraverts. The researchers postulate that this result could be due to the participants' negative attitude either toward their field of study or learning English. Therefore, they did not answer the MBTI questions precisely and were not interested in classroom activities as much as the extraverts and introverts were. As a result, their mean scores on the components of the AIQ-IV did not change before and after the treatment.

The present study finds support from several researchers who have verified the relationship between L2 learning and identity and have emphasized the role of learner identity in second language acquisition (e.g., Block, 2006; Kramsch, 2003, 2007). As Grover and Pea (2013) put forward, considering the role of sociocultural perspectives rather than mainly focusing on cognitive orientations to learning can be useful in the identity formation of learners. In line with Kayaoğlu (2013), the findings show that introvert participants were successful in "mental operations to ease the acquisition, retrieval, storage, and use of information for both comprehension and production" (p. 823), and this achievement could stimulate the process of identity formation.

\section{Conclusion}

The aim of ESP is usually to empower students to use language in a target professional situation. Learning a profession involves the learner taking on a new identity, including the values and perspectives of members of the job. Having a professional identity is an essential factor for ESP learners as it guarantees their success in their future careers. Overall, attention to identity can contribute to the education of learners who are going to work in different professions, which might affect the social, economic, and educational settings of a country. However, the current study showed that selecting a variety of classroom activities can encourage learners to change their learning habits and preferences that are the result of personality traits. This study suggests that ESP teachers and practitioners pay attention to the personality of the learners, which might lead to gaining identity necessary for future success in any profession.

\section{References}

Achilles, R. (2018). Emotion, language, and identity: Using language revitalization techniques to create lowanxiety learning environments (Unpublished doctoral dissertation). The University of British Columbia, Canada. Retrieved from https://open.library.ubc.ca/cIRcle/collections/ubctheses/24/items/1.0365807

Al Rhyiami, T. (2014). Exploring Omani ESL learners' identity construction in a study abroad context. International Journal of Bilingual \& Multilingual Teachers of English, 2(1), 65-77. https://doi.org/10.12785/IJBMTE/020106

Albassri, I. (2016). Needs-analysis-informed teaching for English for Specific Purposes. (Unpublished doctoral dissertation). California State University. Retrieved from https://scholarworks.lib.csusb.edu/etd/274/

Allport, G. (1954). The nature of prejudice. Reading. MA: Addison-Wesley.

Arnold, J. (2019). The importance of affect in language learning. Neofilolog, 52(1), 11-14. https://doi.org/10.14746/n.2019.52.1.2

Arnold, J., \& Murphey, T. (Eds.). (2013). Meaningful action: Earl Stevick's influence on language teaching. 
Cambridge: Cambridge University Press.

Aydemir, A. (2013). The relationship between cultural identity and accent. Retrieved from http://www.thesis.bilkent.edu.tr/0006355.pdf

Barton, A., \& Tan, E. (2010). We be burnin'! Agency, identity, and science learning. The Journal of the Learning Sciences, 19(2), 187-229. https://doi:10.1080/10508400903530044

Belcher, D., \& Lukkarila, L. (2011). Identity in the ESP context: Putting the learner front and center in needs analysis. In D. Belcher, A. Johns, \& B. Paltridge (Eds.), New directions in English for specific purposes research (pp. 73-93). Ann Arbor: The University of Michigan. https://doi.org/10.3998/mpub.371075

Belcher, D., Johns, A., \& Paltridge, B. (Eds.). (2011). New directions in English for specific purposes research. Ann Arbor: University of Michigan Press. https://doi.org/10.3998/mpub.371075

Berzonsky, M. (1992). Identity styles and coping strategies. Journal of Personality, 60(4), 771-788. https://doi.org/10.1111/j.1467-6494.1992.tb00273.x

Block, D. (2006). Multilingual identities in a global city: London stories. London: Palgrave. https://doi.org/10.1057/9780230501393

Block, D. (2007). The rise of identity in SLA research, post Firth and Wagner (1997). The Modern Language Journal, 91, 863-876. https://doi.org/10.1111/j.1540-4781.2007.00674.x

Boeree, C. (1998). Hans Eysenck and Other Personality Theories. Retrieved from https://webspace.ship.edu/cgboer/perscontents.html

Brown, J. (2016). Needs analysis and English for specific purposes. London: Routledge. https://doi.org/10.4324/9781315671390

Bucholtz, M., \& Hall, K. (2005). Identity and interaction: A sociocultural linguistic approach. Discourse Studies, 7 (4-5), 585-614. https://doi.org/10.1177/1461445605054407

Campion, G. (2016). 'The learning never ends': Exploring teachers' views on the transition from general English to EAP. Journal of English for Academic Purposes, 23, 59-70. https://doi.org/10.1016/j.jeap.2016.06.003

Cheek, J. M., \& Briggs, S. R. (2013). Aspects of Identity Questionnaire (AIQ-IV). Measurement Instrument Database for the Social Science. Retrieved from http://www.midss.ie

Clancy, S., \& Dollinger, S. (1993). Identity, self, and personality: Identity status and the five-factor model of personality. Journal of Research on Adolescence, 3(3), 227-245. https://doi.org/10.1207/s15327795jra0303_2

Collinger, S. M. C. (1995). Identity styles and the five-factor model of personality. Journal of Research in Personality, 29(4), 475-479. https://doi.org/ 10.1006/jrpe.1995.1028

Cook, V. (1994). Universal grammar and the learning and teaching of second languages. Cambridge: Cambridge University Press. https://doi.org/10.1017/CBO9781139524605.004

Costa, Jr, P., \& McCrae, R. (2013). Personality in adulthood: A five-factor theory perspective. London: Routledge.

Costa, P., \& McCrae, R. (1985). The NEO Personality Inventory manual. Odessa, FL: Psychological Assessment Resources. https://doi.org/10.1037/t07564-000

Duff, P. (2012). Identity, agency, and second language acquisition. In S. Gass, \& A. Mackey (Eds.), The Routledge handbook of second language acquisition (pp. 410-426). New York, NY: Routledge. https://doi.org/10.4324/9780203808184

Ellis, R. (1997). Second Language Acquisition. Oxford: Oxford University Press. https://doi.org/10.1017/S0272263197231074

Eysenck, H. (1972). The structure of human personality. London: Routledge \& KeganPaul.

Eysenck, H. J., \& Eysenck, M. W. (1985) Personality and individual differences: A natural science approach. New York, NY: Plenum. https://doi.org/10.1007/978-1-4613-2413-3

Firth, A., \& Wagner, J. (1997). On discourse, communication, and (some) fundamental concepts in SLA research. The Modern Language Journal, 81, 285-300. https://doi.org/10.2307/329302

Grover, S., \& Pea, R. (2013). Computational thinking in K-12: A review of the state of the field. Educational Researcher, 42(1), 38-43. https://doi.org/10.3102/0013189x12463051

Hall, S. (1996). Introduction: “Who Needs Identity?”. In S. Hall, \& P. Gay (Eds.), Questions of cultural identity 
(pp. 1-17). London: Sage. https://doi.org/10.4135/9781446221907.n1

Hernández, A. (2017). Exploring language learner Identity, learner socialization and language learning in young English language learners (Unpublished master's thesis). University of Guanajuato, Mexico. Retrieved from http://www.repositorio.ugto.mx/handle/20.500.12059/406

Jung, C. (2013). The essential Jung: selected and introduced by Anthony Storr. Princeton, NJ: Princeton University Press. https://doi.org/10.2307/j.ctt46n45n

Kayaoğlu, M. (2013). Impact of extroversion and introversion on language-learning behaviours. Social Behaviour \& Personality: An International Journal, 41(5), 819-825. https://doi.org/10.2224/sbp.2013.41.5.819

Kinginger, C. (2004). Alice doesn't live here anymore: Foreign language learning and identity construction. In A. Pavlenko, \& A. Blackledge (Eds.), Foreign language learning and identity construction (pp. 219-242). London: Cromwell Press. https://doi.org/10.21832/9781853596483-010

Kramsch, C. (2007). The multilingual subject.Oxford: Oxford University Press.

Kramsch, C. (Ed.). (2003). Language acquisition and language socialization. London: Continuum.

Kroskrity, P. (2000). Identity. Journal of Linguistic Anthropology, 9(1-2), 111-114. https://doi.org/10.1075/hop.14.lan6

Lave, J., \& Wenger, E. (1991). Situated learning: Legitimate peripheral participation. Cambridge: Cambridge University Press. https://doi.org/10.1017/CBO9780511815355

Lounsbury, J., Levy, J., Leong, F., \& Gibson, L. (2007). Identity and personality: The big five and narrow personality traits in relation to sense of identity. Identity: An International Journal of Theory and Research, 7(1), 51-70. https://doi.org/10.1080/15283480701319641

Lujić, R. (2018). Classroom participation as a performative act of language learners' identity construction. Language and Cultural Education, 6(3), 72-84. https://doi.org/10.2478/jolace-2018-0025

Mujembari, A., Sharifi, H., \& Looyeh, M. (2011). Identity detection models among Iranian adolescents. ProcediaSocial and Behavioral Sciences, 30, 803-811. https://doi.org/10.1016/j.sbspro.2011.10.156

Myers, I. B., McCaulley, M. H., Quenk, N. L., \& Hammer, A. L. (2009). MBTI Manual: A guideto the development and use of the Myers-Briggs Type Indicator (3rd ed.). Palo Alto, CA: Consulting Psychologists Press.

Myers, I., \& McCaulley, M. (1985). A guide to development and use of the Myers-Briggs Type Indicator Manual. Palo Alto, CA: Consulting Psychological Press.

Norton, B. (1997). Language, identity, and the ownership of English. TESOL Quarterly, 31(3), 409-429. https://doi.org/10.2307/3587831

Norton, B. (2013). Identity and language learning: Extending the conversation. (2nd ed.) Bristol: Multilingual Matters. https://doi.org/10.21832/9781783090563

Norton, B., \& Toohey, K. (2002). Identity and language learning. In R. Kaplan (Ed.), The Oxford handbook of applied linguistics (pp. 115-123). New York, NY: Oxford University Press.

Norton, B., \& Toohey, K. (2011). Identity, language learning, and social change. Language Teaching, 44(4), 412446. https://doi.org/10.1017/S0261444811000309

Pavičić Takač, V., \& Požega, D. (2011). Personality traits, willingness to communicate and oral proficiency in English as a foreign language. In L. Pon, V. Karabali, \& S. Cimer (Eds.), Applied linguistics today: Research and perspectives (pp. 67-82). Berlin: Peter Lang.

Peirce, B. N. (1995). Social identity, investment, and language learning. TESOL Quarterly, 29(1), 9-31. https://doi.org/10.2307/3587803

Rajagopalan, K. (2005). Postcolonial world and postmodern identity: Some implications for language teaching. DELTA: Documentação de Estudos em Lingüística Teórica e Aplicada, 21(SPE), 11-20. https://doi.org/10.1590/S0102-44502005000300003

Rashtchi, M., \& Aghili, H. (2014). Computerized input enhancement versus computer-assisted glosses: Do they affect vocabulary recall and retention? Theory and Practice in Language Studies, 4(8), 1665-1674. https://doi.org/10.4304/tpls.4.8.1665-1674

Rashtchi, M., \& Keyvanfar, A. (2007). ELT Quick 'n' Easy. Tehran: Rahnama.

Rashtchi, M., \& Khoshnevisan, B. (2009). Audiotaped dialogue journal: A technique to improve speaking skill of 
Iranian EFL learners. The Journal of Applied Linguistics, 1(3), 164-176. Retrieved from https://www.researchgate.net

Rashtchi, M., \& Sanayi Mashhour, H. (2019). Extravert and introvert EFL teachers: How do reflective teaching and burnout relate? Journal of Applied Linguistics and Language Research, 6(3), 73-88. Retrieved from http://www.jallr.com/index.php/JALLR/article/view/1012/pdf1012

Rashtchi, M., \& Tollabi Mazraehno, M. R. (2019). Exploring Iranian EFL learners' listening skills via TED talks: Does medium make a difference? Journal of Language and Education, 5(4), 81-97. https://doi.org/10.17323/jle.2019.9691

Reynolds, K., \& Turner, J. (2006). Individuality and the prejudiced personality. European review of social psychology, 17(1), 233-270. https://doi.org/10.1080/10463280601050880

Rottava, L., \& Silva, A. M. (2014). Language learning, identity, and globalization: Learners of Brazilian Portuguese in England and learners of English and Spanish in Brazil. Acta Scientiarum: Language and Culture, 36(2), 171-181. https://doi.org/10.4025/actascilangcult.v36i2.21906

Sharp, A. (2004). Language learning and awareness of personality type in Chinese settings. Asian EFL Journal, 6(2), 1-13. Retrieved from https://www.asian-efl-journal.com

Sharp, A. (2008). Personality and second language learning. Asian Social Science, 4(11), 17-25. https://doi.org/10.5539/ass.v4n11p17

Stojković, N. (2018). English for specific purposes as a linguistic response to globalization. Folia Linguistica et Litteraria, 25, 7-14. https://doi.org/10.31902/fll.25.2018.1

Tejada Reyes, V. (2018). Psychological Personality Factors in Learning English Foreign Language. Online Submission. Retrieved from https://eric.ed.gov/?id=ED592408

Weyreter, M., \& Viebrock, B. (2014). Identity construction in adult learners of English for Specific Purposes (ESP): Exploring a complex phenomenon. In d. Abendroth-Timmer \& E. M. Hening (Eds.). Plurilingualism and Multiliteracies. Frankfurt: Peter Lang. Retrieved from https://www.peterlang.com

Zafar, S., Zaved Khan, \& Meenakshi, K. (2017). Extraversion-introversion tendencies and their relationship with ESL proficiency: A study of Chinese students in Vellore, India. Pertanika Journals Social Sciences and Humanities, 25(2), 687-704. Retrieved from https://www.researchgate.net

\section{Appendix A}

\section{Needs Analysis Survey}

\section{Please answer the following questions to improve the quality of the ESP Course you have taken.}

1- Please write your expectations from the Specialized English Course.

2- Which of the four skills of listening, speaking, reading, and writing do you think should be emphasized in class? Use numbers $(1,2,3,4)$ to show their importance.

3- Do you think technology can enhance learning? Yes O No O

4- Do you like to have lectures in the class? Yes O No O

5- Do you wish to translate from and to English? Yes O No O

6- Do you like to have group work activities in the class? Yes O No O

7- Do you prefer the use of $\mathrm{L} 1$ in class?

8- To what extent do you think grammar should be covered in the class?

9- What type of passages do you prefer to practice reading in class?

10- Please write down any additional comments you think the teacher should know.

\section{Copyrights}

Copyright for this article is retained by the author(s), with first publication rights granted to the journal.

This is an open-access article distributed under the terms and conditions of the Creative Commons Attribution license (http://creativecommons.org/licenses/by/4.0/). 